\title{
LOCURI UITATE - ACUPUNCTURĂ URBANĂ
}

conf. dr. arh. Andra Panait

Universitatea de Arhitectură și Urbanism „Ion Mincu”, București

andra.panait@uauim.ro

\section{Rezumat}

Lucrarea are drept pretext ultimul proiect al anului 3 „De la oraș la program” și este o reflecție asupra spațiului și arhitecturii publice privite nu doar ca fenomen social, ca loc care adună ci și prin prisma felului arhitecturii de a fi expusă privirii, de a se exprima în afară, identificând ceea ce îi poate genera caracterul: o anumită dispunere a golurilor, modelări ale frontului construit, gradări de spații prin dispozitive de intermediere, subordonări de elemente care țin de o scară mai redusă și care invită la a te opri.

Zona propusă studiului se află în centrul istoric al Bucureștiului, în lungul Căii Moșilor. Ca parte a unei strategii de revitalizare eficiente, pe lângă intervențiile de reabilitare a imobilelor aflate în stadiu avansat de degradare, intervențiile punctuale de tip acupunctură urbană ce operează la scară mică au rolul lor atât ca factor de coeziune a vecinătăților de cartier cât și la scara orașului. Pentru locuitori, peisajul istoric reprezintă mediul lor de viață și locul de desfășurare al activităților cotidiene, el se înscrie în memoria socială colectivă si devine purtător de semnificații și de identitate. Este importantă așadar identificarea și păstrarea acestor locuri cu valoare identitară și tocmai de aceea programul propus de fiecare student a căutat să exploreze critic și creativ vocația publică a zonei și amplasamentului, in sensul recuperării acestor locuri, reflectând asupra relațiilor dintre spaţiul public al străzii, spațiile exterioare cu utilizare publică, aflate pe parcelă și accesibile permanent și spațiile interioare și exterioare ale construcției propuse, aflate în raporturi ierarhizate de scară, destinație și semnificație.

Cuvinte cheie: spațiu public, terrain vague, mediere, complexitate spațială, metodă de predare 


\section{Tema}

Tema acestui proiect a avut drept obiect de studiu locul arhitecturii și al spațiului public în devenirea orașului. Spațiul public este folosit în sensul definit de Hannah Arendt (1958) în lucrarea Condiția umană astfel:

Termenul public desemnează două fenomene strâns legate între ele, însă nu întru totul identice: el se referă mai întâi la faptul că tot ceea ce apare în public poate fi văzut și auzit de toată lumea, având parte de cea mai largă publicitate cu putință. Pentru noi, ceea ce se arată - adică este văzut și auzit atât de alții, cât și de noi înșine - constituie realitatea. [...] În al doilea rând, termenul „public” se referă la lumea însăși, în măsura în care aceasta ne este comună tuturor și se distinge de locul pe care îl deținem în mod privat în ea. Ea se leagă mai curând de artificialul uman, precum și de treburile care se desfășoară în mijlocul celor ce locuiesc împreună. A trăi împreună în lume înseamnă în esență că o lume de obiecte se găsește între cei ce au în comun lumea, tot așa după cum masa este așezată între cei ce stau în jurul ei; lumea, ca orice entitate intermediară, îi leagă și îi separă în același timp pe oameni. (p.46-53)

Tema este o reflecție asupra spațiului și arhitecturii publice privite nu doar ca fenomen social, ca loc care adună ci și prin prisma felului arhitecturii de a fi expusă privirii, de a se exprima în afară, identificând ceea ce îi poate genera caracterul: o anumită dispunere a golurilor, modelări ale frontului construit, gradări de spații prin dispozitive de intermediere, subordonări de elemente care țin de o scară mai redusă și care invită la a te opri (cum ar fi o fântână, un arbore, o textură, un pavaj, un loc de stat, o umbrire, o protecție) etc. În cadrul atelierului am propus zona Caii Moșilor vechi, stradă cu puternică vocație publică dar cu o textură urbană în degradare. Tema a inclus două etape: într-o primă fază a avut ca scop studiul interstițiilor, al spațiilor liminale și ariilor vagi.

Au fost alese în urma parcurgerii zonei o suită de situri care au stat la baza studiului și pentru care au fost propuse mici intervenții cu rol de revitalizare urbană, iar în etapa a doua, după lecturarea și aproprierea zonei, conceperea unor clădiri cu destinație publică și a unor spații publice exterioare asociate acestora - de la etapa de inserție urbană până la detaliul de arhitectură.

\section{Obiectivele}

Obiectivele urmărite au fost: înțelegerea prin proiect a sensului public al arhitecturii, a dimensiunii etice a profesiunii și a relațiilor complexe dintre arhitectură și oraș; înțelegerea activă a programului de arhitectură și a procesului de proiectare; explorarea complexității spațiale și a relațiilor dintre spații cu dimensiuni, roluri și semnificații diferite, în interiorul unui ansamblu arhitectural coerent.

\section{Metoda}

Lucrarea de față propune o exemplificare a procesului de predare, printr-o metodă de studiu structurată, bazată pe de-o parte pe anumite tipuri de instrumente de lectură urbană și întrebări care punctează categorii de probleme, ale căror răspunsuri s-au concretizat în tipuri de intervenții, dar care au condus în final la soluții particulare: Ce este acela un spațiu public, cum a evoluat acesta din antichitate până în prezent, cum s-au modificat funcțiile tradiționale ale străzii de-a lungul timpului, cum se poate interveni într-un mediu eterogen cu probleme sociale, care sunt tendințele actuale în ceea ce privește diminuarea traficului pentru a avea un oraș locuibil, atractiv, sigur și sustenabil. 


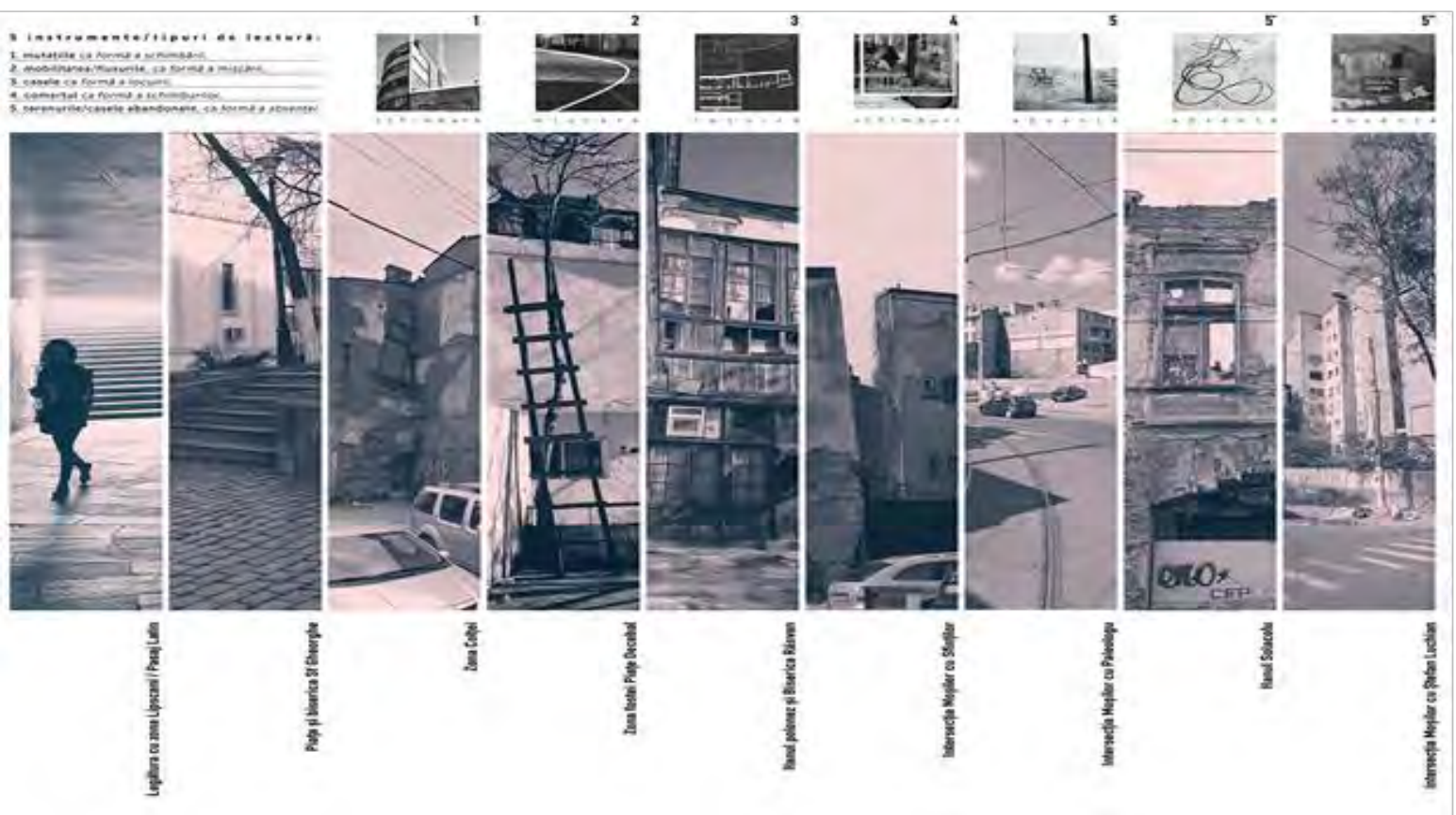

Fig. 1. Lectura urbană pe paliere diferite de intervenție. Sursa: Andra Panait, imagine din materialul prezentat la expoziție

Lectura urbană (Fig. 1) a urmărit cinci instrumente sau tipuri de lectură:

1. mutațiile ca formă a schimbării,

2. mobilitatea/fluxurile, ca formă a mișcării,

3. casele ca formă a locuirii,

4. comerțul ca formă a schimburilor,

5. terenurile/casele abandonate, ca formă a absenței.

\section{Proiectele}

Tipurile de intervenții s-au concentrat atât pe recuperarea fondului de patrimoniu existent, cât și pe soluții care au vizat reconfigurări ale spațiului public împreună cu noi strategii de mobilitate urbană. Aceste decizii au fost luate în urma unei cercetări istorice cu scopul de a păstra specificul zonei și de a pune în valoare patrimoniul construit.

Valentin Podeanu (1935) în revista Realitatea ilustrată descria necesitățile urbanistice care „fac ca labirintul alcătuit din prăvăliile si pavilioanele acestor străzi să-și trăiască acum ultimele zile, urmând ca peste trupul vechilor și glorioaselor ulițe să se croiască în zilele noastre bulevardul larg de 50 de metri care va contribui, împreună cu celelalte modernizări, să facă din București o metropolă a peninsulei Balcanice și poate a Orientului European."

Acest bulevard, astăzi Ion Brătianu, acționează ca o limită fermă și separă Zona Lipscani de Zona Căii Moșilor. 


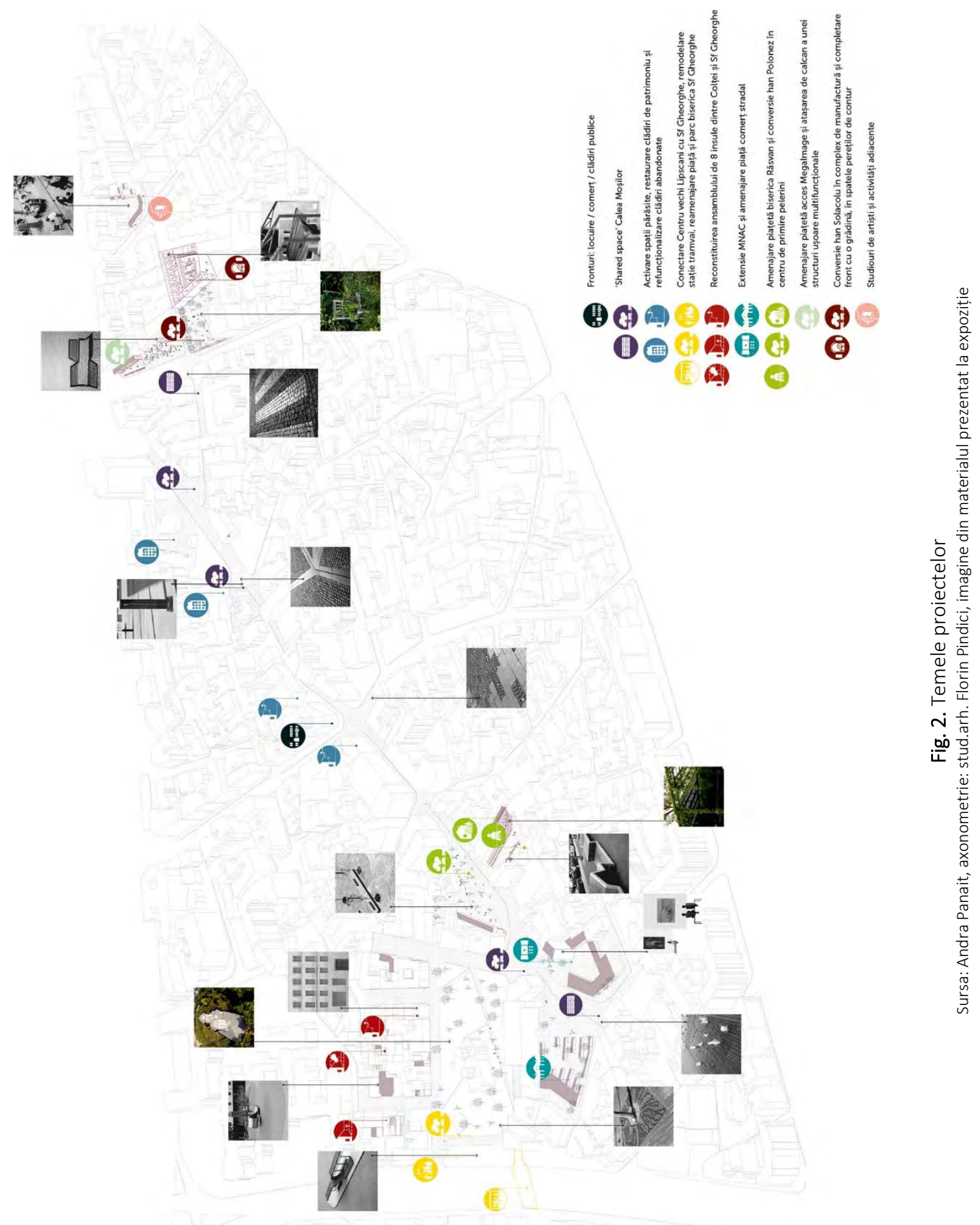








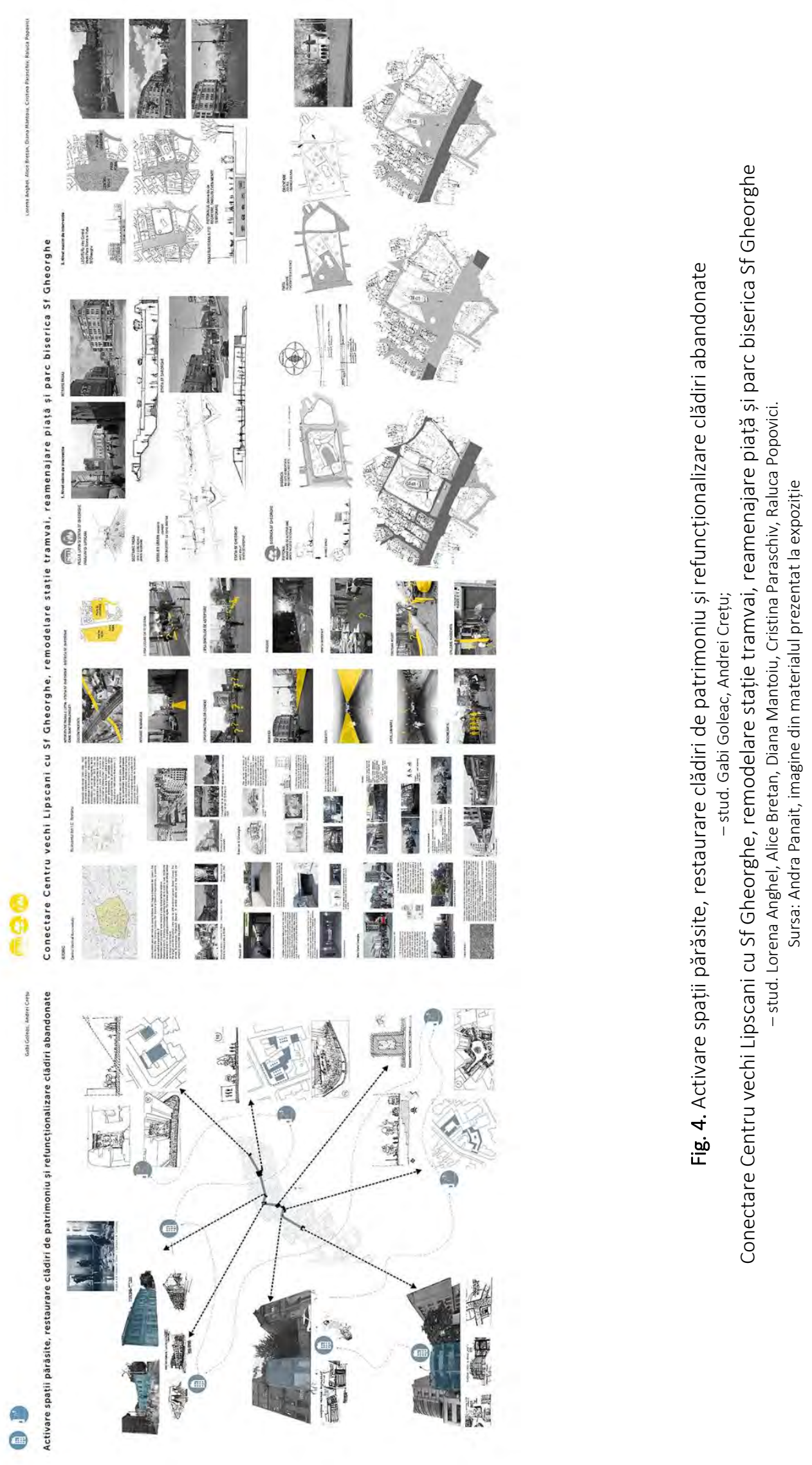

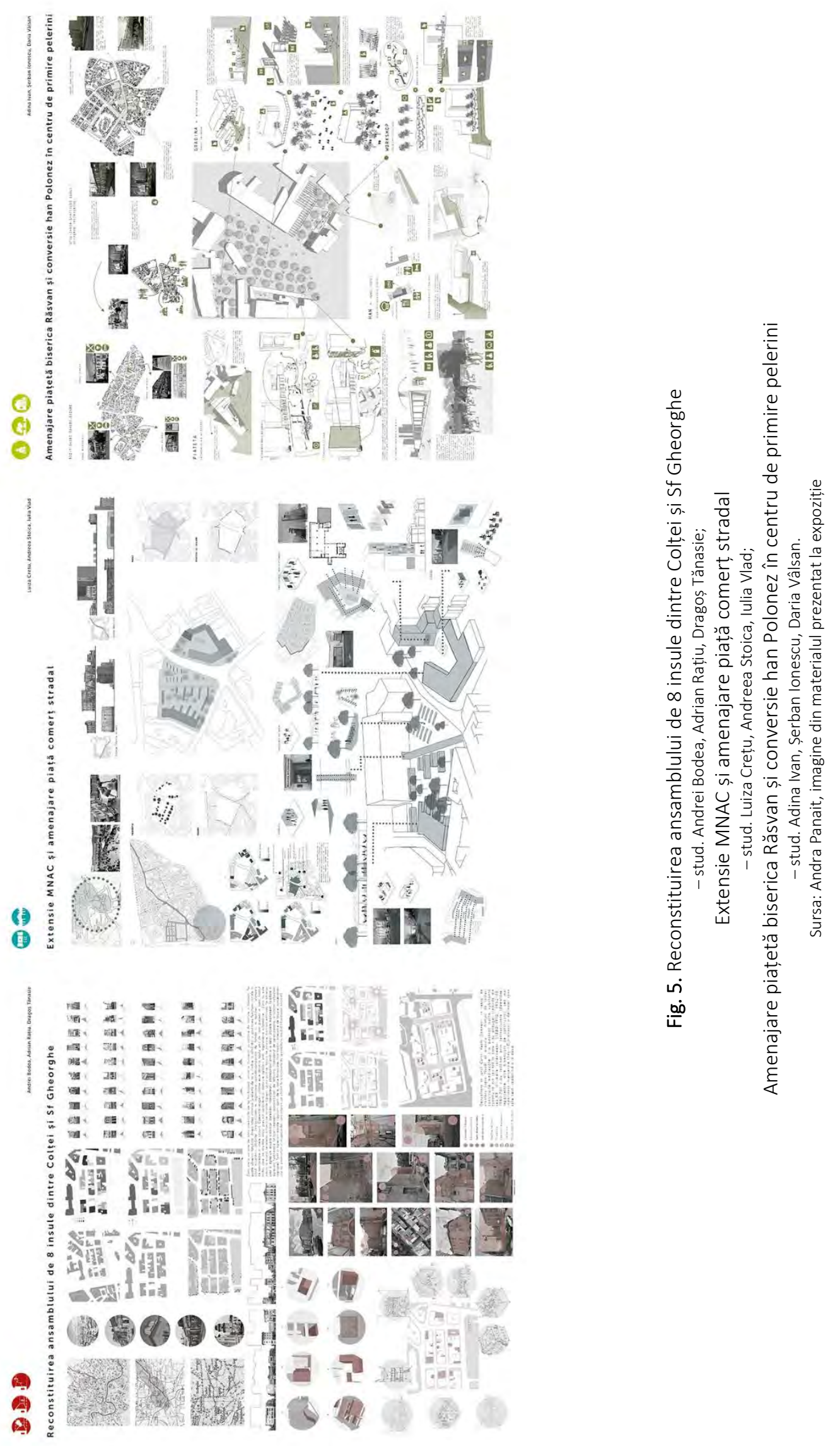

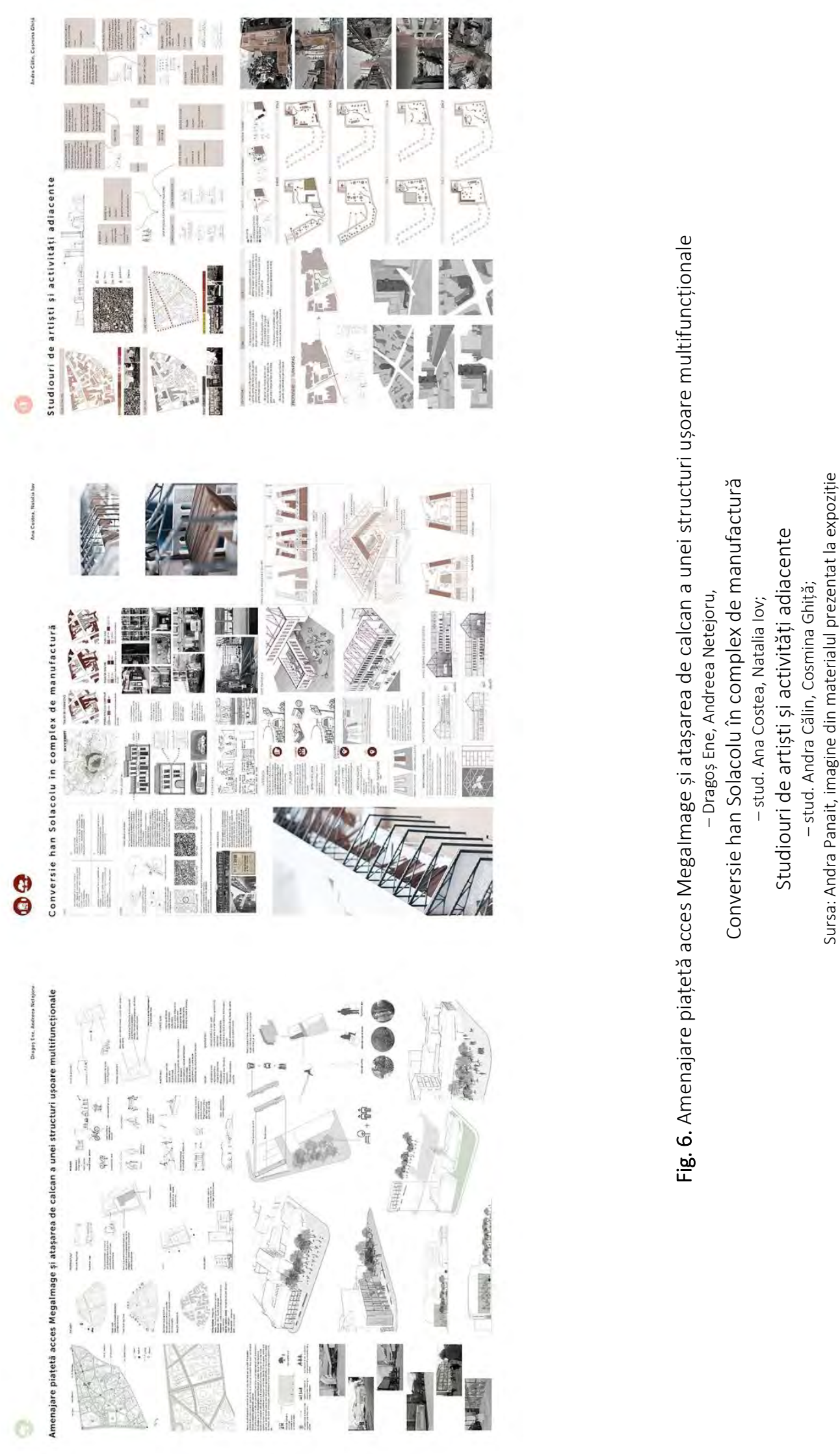
De aceea am propus întărirea legăturii dintre centrul vechi zona Lipscani și zona Căii Moșilor vechi, despărțită prin pasajul pietonal Sf Gheorghe de bulevardul Ion Brătianu care acționează în prezent ca o barieră. Conform Planului de mobilitate urbană durabilă 2016-2030 - Regiunea București - Ilfov am propus transformarea carosabilului actual într-un spațiu pietonal, cu păstrarea transportului public, tramvaiul cu cai fiind un element „mnemonic" prezent încă din 1872, după cum rezultă din scrierile vremii (Podeanu, 1935) - Piața Sf Gheorghe-Roma a fost traversată de tramvaie încă de la inaugurarea primei linii de tramvaie cu cai (1872). Piața era punct nodal al circulației, toate liniile plecau de aici spre Teatrul Cel Mare si Calea Târgoviștei (Griviței), spre Calea Călărași și Moșilor până la Obor, spre Văcărești până la Uzinele Lemaitre (azi Timpuri Noi).

Celelalte proiecte propun conversii și intervenții noi care să acționeze punctual, la scară mică atât ca factor de coeziune a vecinătăților de cartier cât și la scara orașului, înțelegând forma urbană ca totalitate a relațiilor ce se stabilesc între spațiul fizic și activitățile sociale din oraș (Kevin Lynch, 1981, p. 47, 48, 280).

Proiectele au avut următoarele teme (Fig. 2):

- Reabilitarea fronturilor: locuire / comerț / clădiri publice (Fig. 3)

- Pietonalul de tip „shared space” Calea Moșilor (Fig. 3)

- Activare spații părăsite, restaurare clădiri de patrimoniu și refuncționalizare clădiri abandonate (Fig. 4)

- Conectare Centru vechi Lipscani cu Sf Gheorghe, remodelare stație tramvai, reamenajare piață și parc biserica Sf Gheorghe (Fig. 4)

- Reconstituirea ansamblului de 8 insule dintre Colței și Sf Gheorghe (Fig. 5)

- Extensie MNAC și amenajare piață comerț stradal (Fig. 5)

- Amenajare piațetă biserica Răsvan și conversie han Polonez în centru de primire pelerini (Fig. 5)

- Amenajare piațetă acces Megalmage și atașarea de calcan a unei structuri ușoare multifuncționale (Fig. 6)

- Conversie han Solacolu în complex de manufactură și completare front cu o grădină, în spatele pereților de contur (Fig. 6)

- Studiouri de artiști și activități adiacente (Fig. 6)

\section{Concluzii}

Până la redescoperirea virtuților de coerență și consistență, de organicitate a țesutului urban medieval de către Aldo Rossi sau Colin Rowe, apoi de către postmoderniști precum Leon şi Rob Krier (Augustin, 2017), obiectul de arhitectură, de sine stătător, dislocat și nerelaționat cu contextul său a fost principalul mod de a se manifesta al arhitecturii moderne. Deconstructiviștii sunt cei care au rafinat conceptul prezenței simultane: co-prezența tuturor sau a cât mai multora dintre ipostazele semnificative prin care au trecut un sit sau o clădire, fiind nu doar dorită, dar chiar necesară casei supuse transformării.

Caracteristica acestor situri, care au făcut obiectul intervențiilor de la atelier, este tocmai coprezența, fiind locuri de mediere care permit intervenții ale căror spații pot fi imprecis definite, 
accidentale, neomogene, discontinue, dar cu o capacitate mare de cuplare, de interconectare. În urma studiului a rezultat că specificitatea acestor spații vagi rezidă tocmai în felul în care ele leagă diferite scări, diferite sfere de influență, diferite sisteme spațiale sau sociale, conturânduse astfel întrebarea: Cum poate arhitectura acționa în aceste spații fără a deveni un instrument agresiv al puterii și al rațiunii abstracte?

lar răspunsul este probabil, parafrazându-I pe Ignasi de Sola Morales (1995): prin atenția la continuitate - nu cea eficientă, legitimă a orașului planificat ci printr-o continuitate a fluxurilor, energiilor, ritmurilor stabilite prin trecerea timpului și prin pierderea limitelor (p. 118-123).

Ariile vagi sunt zone în care se întâlnesc mai multe funcțiuni diferite, sunt efemere, evazive, au calitățile granițelor, dar, care, chiar dacă la prima vedere sunt sub formă de linii, la o privire mai apropiată devin arii de nuanțe, nedeterminate, imprecise, neclare.

Proiectele au răspuns acestei situației urbane particulare, privind orașul ca o suita de straturi, de registre distincte suprapuse în timp, care nu trebuie interpretate prin omogenizare sau reducție. Ele au vorbit despre nevăzutul unui obiect în timp și despre evenimentul spațial care poate produce o recuperare - precum momentul madlenei lui Proust, ca declanșator senzorial.

De asemenea, au încercat punerea în valoare a spațiului public readus la statutul de stradă comercială prin concentrarea măsurilor în proiecte mici dar cu efect sinergic, pe trasee cu potențial de conectare a zonelor de interes, având în vedere creșterea calității utilizării spațiului public pentru diferite activități, parcurgerea cu minim de obstacole, posibilități de repaos prin mobilier urban, delimitarea unor zone pentru activități cultural performative (spectacole și concerte) și activități comerciale temporare (piețe și târguri urbane), corelarea traficului motorizat cu parcurgerea prioritar pietonală și pe bicicletă a spațiului public, delimitarea strictă a locurilor de parcare, amenajare peisajeră și iluminare arhitecturală a spațiului public și a elementelor valoroase de arhitectură și artă monumentală, intervenții punctuale pentru compensarea efectului de "golire” comercială a zonei centrale datorită concurenței disproporționate a centrelor comerciale și combaterea declinului urban, corelarea cu modul de accesibilitate al acestor zone, preponderent pietonal și cu o bună deservire de către transportul public.

\section{Referinţe}

Arendt, H. (1958), The Human Condition, The University of Chicago

Bachelard, G. (2003). Poetica spaţiului. (I. Bădescu, Trans.). Piteşti: Paralela 45.

de Solà-Morales, I. (1995). Terrain vague. In Cynthia Davidson (Ed.). Anyplace, Cambridge, MA: MIT Press.

Heiner, M. (2005) MSC Maximal Stress Cooperation: The Driving Force of Cultures, Springer

Ioan, Augustin (2017) Locuind în vag, https://atelier.liternet.ro/articol/17703/Augustin-Ioan/Locuindin-vag.html, accesat în 2019

Lynch, K. (1981), A Theory of Good City Form, Cambridge MA: The MIT Press

Planul de mobilitate urbană durabilă 2016-2030 - Regiunea București - Ilfov, http://tpbi.ro/files/proiect_pmud.pdf, accesat în 2019

Podeanu, V. contributor (1906-1942), Revista Realitatea ilustrată, August 1935, Ed. Bucureşti: Atelierele "Adevărul" 
conf. dr. arch. Andra Panait

"Ion Mincu"University of Architecture and Urban Planning, Bucharest

andra.panait@uauim.ro

\begin{abstract}
This paper has as a pretext the last project of 3rd year "From the city to the program" and this is a reflection on public space and public architecture seen not only as a social phenomenon, or as a place that gathers, but also in terms of the way architecture is exposed to view, to express itself outside, identifying what its character can generate: a certain arrangement of gaps, modeling of the built front, gradations of spaces through intermediation devices, subordinations of elements that belong to a smaller scale and that invite you to stop.

The studied area is located in the Old Center of Bucharest, along Calea Moșilor. As part of a strategy to efficiently revitalize the city, aside from the rehabilitation interventions of advanced decayed buildings, the use of urban acupuncture-type of localized interventions, which solely works on small-scale architectural objects, has the purpose of acting as a cohesion between both the different areas of the neighborhood and the city itself. To the residents, the historical landscape is their living environment, which acts as a background for their daily activities, it is a part of their social collective memory and has become a bearer of meaning and identity. It is therefore important to identify and preserve these places of identity value, and that is why the program proposed by each student sought to critically and creatively explore the public vocation of the area and site, in the sense of recovering these places, reflecting on the relations between the public space of the street, the outdoor spaces with public use, located on the plot and permanently accessible and the interior and exterior spaces of the proposed construction, in hierarchical relationships of scale, destination and significance.
\end{abstract}

Keywords: public space, terrain vague, mediating, spatial complexity, teaching method 


\section{Theme}

The project had as major theme the place of architecture and public space in the growth of the city. Public space is used in the meaning defined by Hannah Arendt (1958) in the book The Human Condition thus:

The public term shall mean two phenomena closely related to each other, but not entirely identical: it first refers to the fact that everything that appears in public can be seen and heard by everyone, having the widest possible publicity. For us, what is shown - that is seen and heard by both others and ourselves - constitute the reality. [..] Secondly, the term "public" refers to the world itself, insofar as it is common to all of us and is distinguished from the place we have privately hold in it. It is more connected to the human artificial, as well as to the tasks that take place in the midst of those who live together. Living together in the world essentially means that a world of objects is found among those who have in common the world, just as the table is placed between those who sit around it; the world, like any intermediary entity, binds and separates people at the same time. (p.46-53)

The theme is a reflection on public space and architecture seen not only as a social phenomenon, as a place that gathers but also in terms of the way architecture is exposed to view, to express itself outside, identifying what its character can generate: a certain arrangement of gaps, modeling of the built front, gradations of spaces through intermediation devices, subordinations of elements that belong to a smaller scale and that invite you to stop (such as a fountain, a tree, a texture, a pavement, a place to sit, a shading, a protection) etc. In the workshop we proposed the area of the old Calea Moșilor, a street with strong public vocation but with an urban texture in constant decay. The theme included two stages: the first phase was aimed at studying interstitions, liminal spaces and vague areas.

After examining the area, a number of sites have been selected as basis of the study. In the first phase small interventions have been proposed for each site as basis of urban revitalization and in the second phase, after reading and approaching the area, designing of public buildings and associated outdoor public spaces were proposed - from urban insertion stage to the architectural detail.

\section{Objectives}

The objectives pursued were: to understand the public sense of architecture through the project, the ethical dimension of the profession and the complex relations between architecture and city; active understanding of the architecture program and the design process; exploring spatial complexity and relationships between spaces with different dimensions, roles and meanings within a coherent architectural ensemble.

\section{Method}

This paper proposes an example of the teaching process, through a structured study method, based on one side on certain types of urban reading tools and questions that point to categories of problems, the answers of which have resulted in types of interventions, but which have ultimately led to particular solutions: What is a public space, how it has evolved from antiquity to the present, how the traditional functions of the street have changed over time, how to intervene in a heterogeneous environment with social problems, what are the current trends in traffic congestion in order to have a habitable, attractive, safe and sustainable city. 


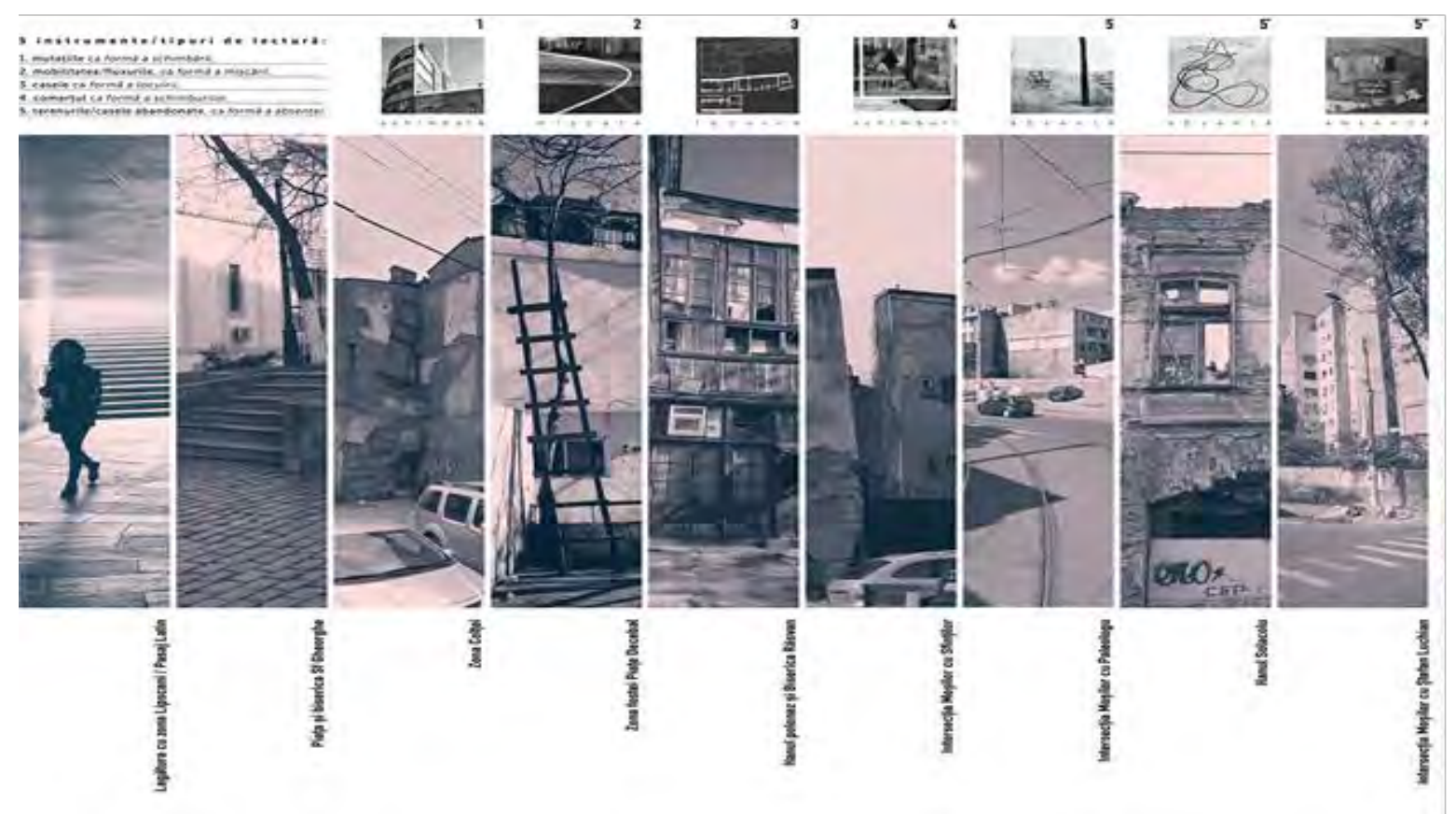

Fig. 1. Urban reading on different levels of intervention. Source: Andra Panait, image of the exhibition material

The urban reading (Fig. 1 ) followed five instruments or types of reading:

1. mutations as the form of change,

2. mobility/flows, as the form of movement,

3. houses as the form of habitation,

4. trade as the form of exchanges,

5. abandoned land/houses, as a form of absence.

\section{Projects}

The types of interventions focused both on the recovery of the existing heritage fund and on solutions that targeted public space reconfiguration along with new urban mobility strategies. These decisions were made following a historical research in order for preserving the specifics of the area and valuing the built heritage.

Valentin Podeanu (1935) in the journal The Illustrated Reality described the urban needs that "make the labyrinth created of the shop and pavilions of these streets to live their last days, following that over the body of the old and glorious alleys to be built nowadays the wide 50meter boulevard that will contribute, together with the other modernizations, to make Bucharest a metropolis of the Balkan peninsula and perhaps of the European Orient."

This boulevard, today Ion Brătianu, acts as a firm boundary and separates the Lipscani area from the Calea Mosilor area. 


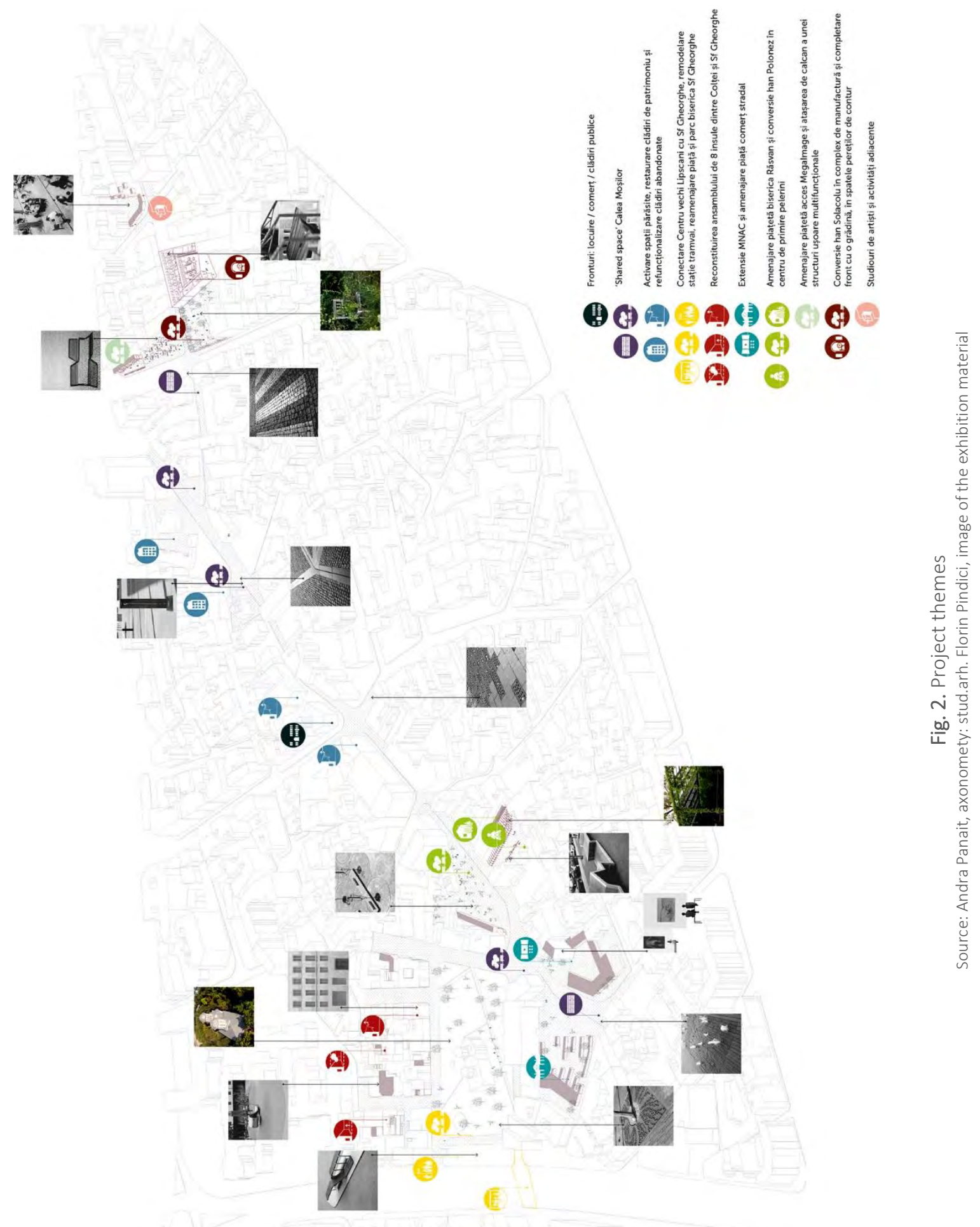




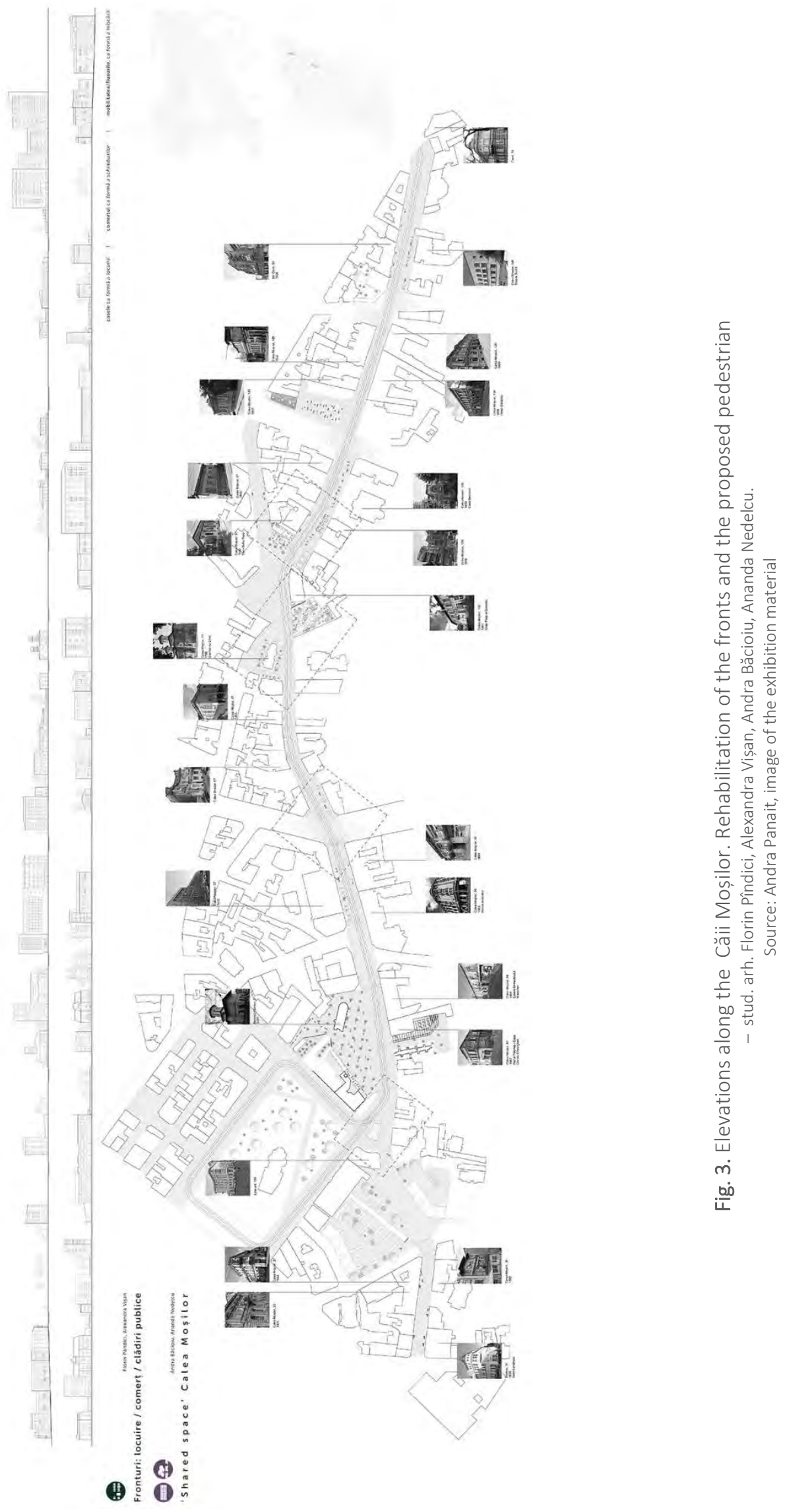



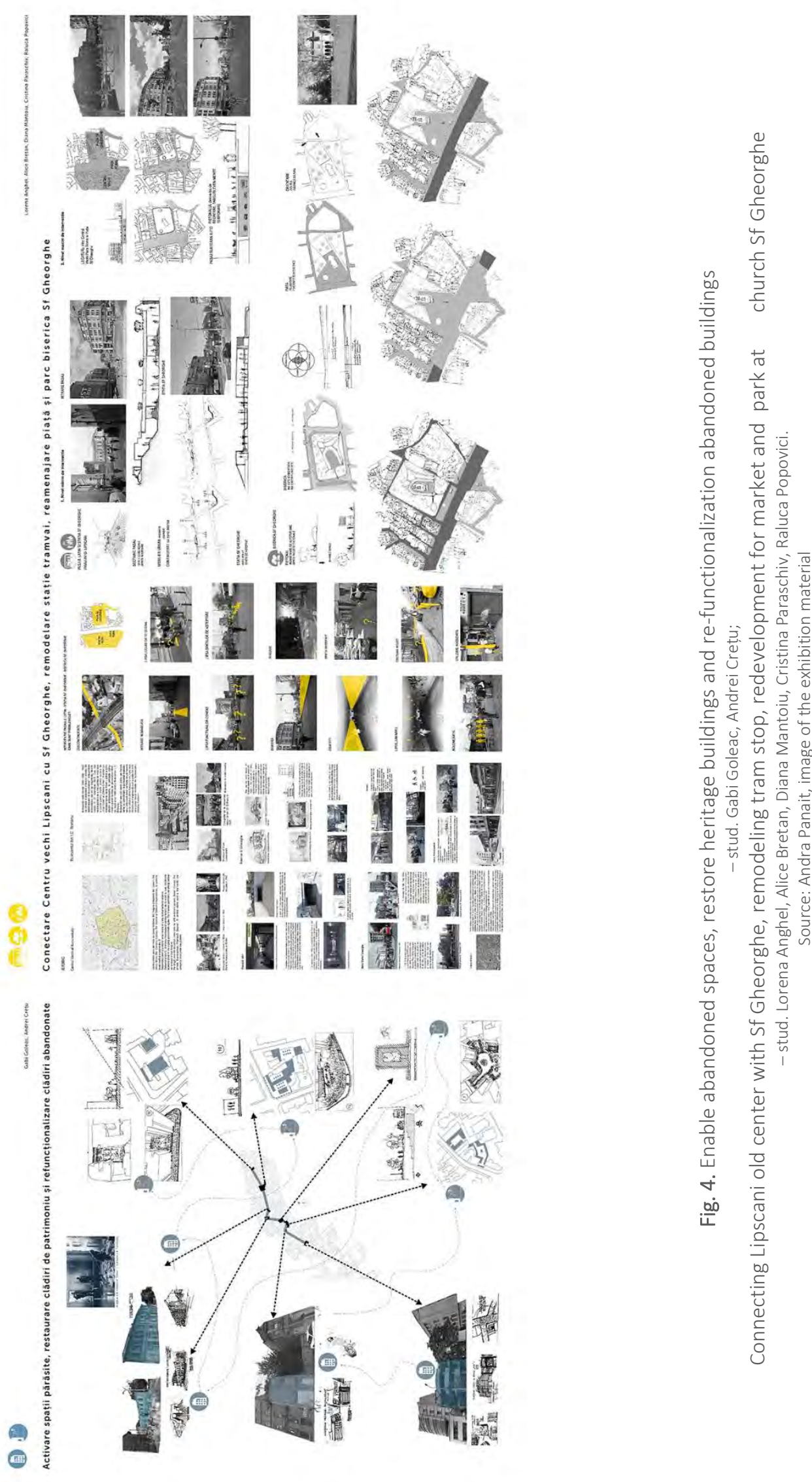

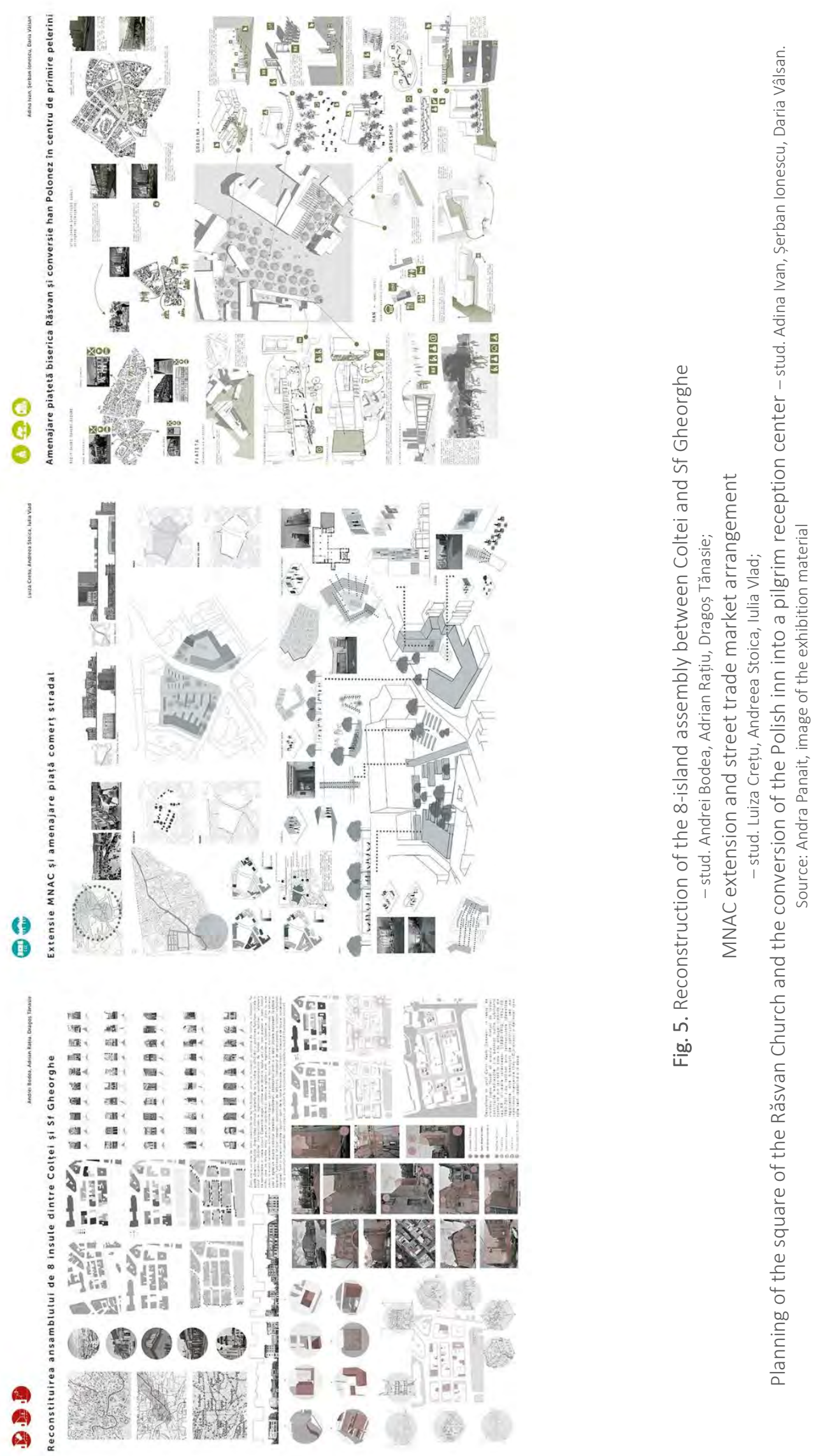

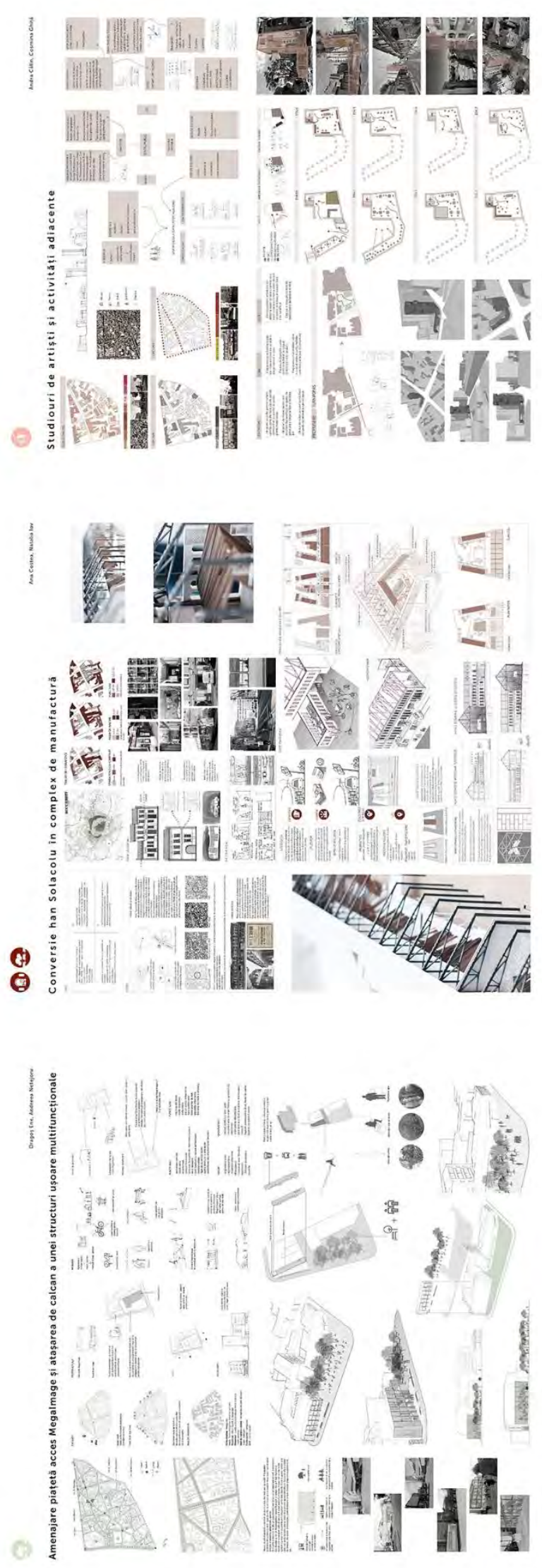
That is why we proposed strengthening the link between the old center Lipscani area and the old Calea Mosilor area, separated by the Sf Gheorghe pedestrian passage from Ion Brătianu boulevard which currently acts as a barrier. According to the Sustainable Urban Mobility Plan 2016-2030 - Bucharest - Ilfov Region we proposed to transform the current road into a pedestrian space, with the preservation of public transport, the horse tram being a "mnemonic" element present since 1872, as it results from writings of the time (Podeanu, 1935) - Sf. Gheorghe-Rome Square has been crossed by trams since the first horse tram line was inaugurated (1872).

The square was a nodal point of circulation, all the lines were going from here to the Great Theatre and Calea Targovistei (Grivitei), to Calea Calarasi and Mosilor up to Obor, to Văcăreşti up to the Lemaitre Factories (today Timpuri Noi).

The other projects propose new conversions and interventions that act on a small scale, both as a cohesion factor of the neighbourhood proximity and on the city scale, understanding the urban form as the totality of the relationships that are established between the physical space and the social activities of the city (Kevin Lynch, 1981, p. 47, 48, 280).

The projects had the following topics (Fig. 2):

- Rehabilitation of fronts: housing / trade / public buildings (Fig. 3)

- Calea Moșilor 'shared space' pedestrian (Fig. 3)

- Enable abandoned spaces, restore heritage buildings and re-functionalization abandoned buildings (Fig. 4)

- Connecting Lipscani old center with Sf Gheorghe, remodeling tram stop, redevelopment for market and park at church Sf Gheorghe (Fig. 4)

- Reconstruction of the 8-island assembly between Coltei and Sf Gheorghe (Fig. 5)

- MNAC extension and street trade market planning (Fig. 5)

- Planning of the square of the Răsvan Church and the conversion of the Polish inn into a pilgrim reception center (Fig. 5)

- Planning of the square with access to Megalmage and attachment of a light multifunctional structure on a blind wall (Fig. 6)

- Conversion of Solacolu inn into manufacturing complex and front completion with a garden, behind the contour walls (Fig. 6)

- Artist studios and adjacent activities (Fig. 6).

\section{Conclusions}

Until the rediscovery of the virtues of coherence and consistency, of the organicity of medieval urban tissue by Aldo Rossi or Colin Rowe, then by postmodernists such as Leon and Rob Krier (Augustin, 2017), the object of architecture, in its own right, dislodged and unrelated to its context was the main way of manifesting itself in modern architecture. Deconstructivists are the ones who have refined the concept of simultaneous presence: the co-presence of all or more of the significant hypostases through which a site or building has passed, being not only desired, but even necessary for the house undergoing transformation. 
The characteristic of these sites, which have been the subject of interventions at the workshop, is precisely co-presence, being places of mediation, which allow interventions whose spaces can be imprecisely defined, accidental, non-homogeneous, discontinuous, but with a large capacity for coupling, interconnection.

The study showed that the specificity of these vague spaces lies precisely in the way in which they connect different scales, different spheres of influence, different spatial or social systems, thus shaping the question: How can architecture act in these spaces without becoming an aggressive instrument of abstract power and reason?

And the answer is probably, paraphrasing Ignasi de Sola Morales (1995): by focusing to continuity - not the efficient, legitimate one of the planned city but by a continuity of flows, energies, rhythms established by the passage of time and by the loss of limits (p. 118-123).

Vague areas are areas where several different functions meet, are ephemeral, elusive, have the qualities of borders, but, even if at first glance are in the form of lines, at a closer look become areas of nuance, indeterminate, imprecise, unclear.

The projects responded to this particular urban situation, regarding the city as a suite of layers, of distinct registers superimposed over time, which should not be interpreted by homogenization or reduction. They talked about the unseen of an object in time and the spatial event that can produce a recovery - such as the moment of Proust's madeleine as a sensory trigger.

Students also tried to enhance public space by concentrating measures in small projects with a synergistic effect, on routes with the potential to connect areas of interest, given the increased quality of use of public space for various activities, crossing with minimum obstacles, opportunities to rest through urban furniture, delimitation of areas for cultural performative activities (shows and concerts) and temporary commercial activities (urban markets and fairs), correlation between motorized traffic with priority pedestrian and bicycle crossing of public space, strict delimitation of parking spaces, landscape planning and architectural illumination of the public space and of the valuable elements of architecture and monumental art, targeted interventions to compensate for the commercial 'empty' effect of the central area due to disproportionate competition of shopping centers and combating urban decline, correlation with the accessibility of these areas, mainly pedestrian and with good service by public transport.

\section{References}

Arendt, H. (1958), The Human Condition, The University of Chicago

Bachelard, G. (2003). Poetica spaţiului. (I. Bădescu, Trans.). Piteşti: Paralela 45.

de Solà-Morales, I. (1995). Terrain vague. In Cynthia Davidson (Ed.). Anyplace, Cambridge, MA: MIT Press.

Heiner, M. (2005) MSC Maximal Stress Cooperation: The Driving Force of Cultures, Springer

Ioan, Augustin (2017) Locuind în vag, https://atelier.liternet.ro/articol/17703/Augustin-Ioan/Locuindin-vag.html, accesat în 2019

Lynch, K. (1981), A Theory of Good City Form, Cambridge MA: The MIT Press 
Planul de mobilitate urbană durabilă 2016-2030 - Regiunea București - Ilfov, http://tpbi.ro/files/proiect_pmud.pdf, accesat în 2019

Podeanu, V. contributor (1906-1942), Revista Realitatea ilustrată, August 1935, Ed. Bucureşti: Atelierele "Adevărul" 